\title{
Phenotypic Variability associated with the C9ORF72 Hexanucleotide Repeat Expansion: A Sporadic Case of Frontotemporal Lobar Degeneration with Prodromal Hyposmia and Predominant Semantic Deficits
}

Carlo Abbate ${ }^{\mathrm{a}, *}$, Beatrice Arosio ${ }^{\mathrm{a}, \mathrm{b}}$, Daniela Galimberti ${ }^{\mathrm{c}, \mathrm{d}}$, Paola Nicolini ${ }^{\mathrm{a}}$, Lo Russo Chiara ${ }^{\mathrm{a}}$, Paolo Dionigi Rossi ${ }^{\mathrm{a}}$, Evelyn Ferri ${ }^{\mathrm{a}}$, Cristina Gussago ${ }^{\mathrm{a}}, \mathrm{b}$, Milena Deriz $^{\mathrm{c}}$, Chiara Fenoglio ${ }^{\mathrm{c}, \mathrm{d}}$, Maria Serpente ${ }^{\mathrm{c}, \mathrm{d}}$, Elio Scarpini ${ }^{\mathrm{c}, \mathrm{d}}$ and Daniela Mari ${ }^{\mathrm{a}, \mathrm{b}}$

${ }^{a}$ Geriatric Unit, University of Milan, Fondazione Cà Granda, IRCCS Ospedale Maggiore Policlinico, Milan, Italy ${ }^{\mathrm{b}}$ Department of Medical Sciences and Community Health, University of Milan, Fondazione Cà Granda, IRCCS Ospedale Maggiore Policlinico, Milan, Italy

${ }^{\mathrm{c} N e u r o l o g y}$ Unit, University of Milan, Fondazione Cà Granda, IRCCS Ospedale Maggiore Policlinico, Milan, Italy ${ }^{\mathrm{d}}$ Department of Pathophysiology and Transplantation, "Dino Ferrari" Center, University of Milan, Fondazione Cà Granda, IRCCS Ospedale Maggiore Policlinico, Milan, Italy

Handling Associate Editor: Chiara Cerami

\begin{abstract}
We describe a sporadic case of frontotemporal lobar degeneration, associated with the C9ORF72 mutation, with prominent behavioral changes and semantic deficits. Predominant deficits in naming, vocabulary, word comprehension, and face and object recognition emerged on neuropsychological assessment. Amnesia, behavioral changes, and isolated psychotic symptoms were also present. Hyposmia was an unspecific prodromal sign. Brain imaging showed basofrontal and temporopolar hypometabolism bilaterally, and predominantly left-sided atrophy. Levels of cerebrospinal fluid biomarkers (amyloid- $\beta$, tau and p-tau) were normal. This description further confirms the heterogeneous presentation of the C9ORF72 mutation.
\end{abstract}

Keywords: C9ORF72, frontotemporal lobar degeneration, hyposmia, phenotype, semantic dementia

\footnotetext{
${ }^{*}$ Correspondence to: Carlo Abbate, Geriatric Unit, Fondazione Cà Granda, IRCCS Ospedale Maggiore Policlinico, Via Pace 9, 20122 Milan, Italy. Tel.: +39 025503 3246; Fax: +39 02 50320735; E-mail: carlo.abbate@guest.unimi.it.
} 


\section{INTRODUCTION}

A hexanucleotide repeat expansion in the C9ORF72 gene has been shown to be responsible for many cases of familial amyotrophic lateral sclerosis or frontotemporal lobar degeneration, with or without concomitant motor neuron disease $[1,2]$. The clinical phenotype of the C9ORF72 carriers is widely heterogeneous, even within the same family. The most common presentation is the behavioral variant of frontotemporal dementia (bvFTD), sometimes accompanied by features of amyotrophic lateral sclerosis [3-10]. Psychosis, obsessive-compulsive disorders, and memory impairment are also frequent symptoms at disease onset [4, 9, 11-13]. In a more limited number of patients, clinical features of progressive nonfluent (PNFA) $[4,5,7,10]$ or semantic variant (SD) $[4,6$, $9,10,14,15]$ of primary progressive aphasias have been reported. Some authors [6] have observed that the occurrence of SD associated with the C9ORF72 mutation was unexpected since patients with SD usually have a negative family history [16], suggesting a masked genetic dominant pattern of inheritance. Therefore, further clinical studies are needed to confirm the association between the repeat expansion in the C9ORF72 gene and the SD phenotype as well as to elucidate the genetic contribution to SD [6]. Here, we describe a sporadic Italian case of frontotemporal lobar degeneration associated with the C9ORF72 mutation, exhibiting a clinical phenotype with predominant semantic deficits.

\section{METHODS}

A neurological, neuropsychological, behavioral, functional, and instrumental evaluation was carried out. Global cognitive functioning was assessed with the Mini-Mental State Examination (MMSE) and the Clock Drawing test (CDT). The neuropsychological assessment included multiple tests to evaluate a range of cognitive functions (i.e., logical-deductive reasoning abilities, pre-frontal functions, insight, psychomotor speed, visuospatial attention [17, 18], anterograde, semantic [19-21] and retrograde memory [22], short-term memory, language, limb and limb-kinetic praxis, constructional functions, object recognition [23]) (Table 1). Behavior was assessed with the Neuropsychiatric Inventory Battery (NPI), functional autonomy with the Activities of Daily Living (ADL) and Instrumental ADL (IADL) scales, and depression with the Geriatric Depression Scale (GDS).
Electroencephalography (EEG), brain magnetic resonance (MR), and $\left[{ }^{18} \mathrm{~F}\right]$-fluorodeoxyglucose-positron emission tomography (FDG-PET) were performed. Lumbar puncture was carried out, and cerebrospinal fluid (CSF) amyloid- $\beta$ (A $\beta$ ), tau, and phosphorylated tau (p-tau) were evaluated by ELISA (Innogenetics, Ghent, Belgium). Progranulin plasma levels were determined by ELISA (Adipogene, Korea). Genomic DNA was extracted from blood using a salting-out method [24] and the C9ORF72 genotyping was accomplished by Repeat-Primed PCR and sequencing [1] which allows detection of about 30 repeats. According to the current literature [3], a characteristic stutter amplification pattern ( $>30$ repeats) on the electropherogram is considered evidence of a pathogenic repeat expansion. Both patient and caregiver provided written informed consent to participation in the study.

\section{CASE REPORT}

The patient came to our attention in 2012 because of subjective memory complaints. He was a right-handed, 69-year-old man, with 13 years of education. His family history was negative for dementia and/or for motor neuron disease. His mother died at 67 years of age due to long-term consequences of a prior stroke, and his father at 69 years of age because of a heart attack. The patient has three siblings, aged 73, 72 and 68, who, so far, do not appear to have any cognitive or motor disturbances. His only known medical condition was mild hypertension. At the visit, his relatives described a complex clinical picture including behavioral changes, cognitive impairments, and psychotic symptoms, all with a subtle onset about three years earlier and a slowly progressive course. The patient had left his wife and family and had gone off to live on his own. He had grown apathetic, progressively losing interest in social interactions as well as emotional involvement with his family. He had taken to keeping the money for himself and spending it on compulsive gambling. Increasing inertia concurrently emerged: he had to be encouraged to properly attend to his personal hygiene. Moreover, his diet had become very restricted. Mild psychotic symptoms were also evident: he had become extremely religious and sometimes manifested mystic/megalomaniac and theft delusions. He had developed subtle dysfunctions in episodic and retrograde as well as semantic memory (e.g., although he owned a small business he no longer knew what "bank loan" meant). Interestingly, hyposmia was a possible unspecific prodromal sign, appearing five years 
Table 1

Neuropsychological assessment

\begin{tabular}{|c|c|c|c|c|}
\hline Test & Patient raw score & Maximum score & Cut-off score & Impairment \\
\hline \multicolumn{5}{|l|}{ General } \\
\hline Mini mental state examination & 29 & 130 & 24 & \\
\hline Raven coloured progressive matrices & 30 & 136 & 17.5 & \\
\hline \multicolumn{5}{|l|}{ Executive functioning } \\
\hline Trail Making Test (TMT) part A & $44 "$ & & $93 "$ & \\
\hline Trail Making Test (TMT) part B & $89 ”$ & & $282 "$ & \\
\hline Digit span backward & 3 & & & \\
\hline Short stroop test (time) & $52.5 ”$ & & $36.92 ”$ & Impaired \\
\hline Short stroop test (errors) & 7.5 & & 4.24 & Impaired \\
\hline Verbal fluency (phonological one) & 13 & & 17 & Impaired \\
\hline Verbal fluency (semantic one) & 12 & & 24 & Impaired \\
\hline Cognitive estimates test (CET) total & 17 & 142 & 18 & \\
\hline Cognitive estimates test (CET) bizarre & 5 & $/ 21$ & 4 & Impaired \\
\hline Weigl's sorting test & 5 & $/ 15$ & 8.1 & Impaired \\
\hline Clinical Insight Rating Scale (CIR) & 3 & 18 & & Impaired \\
\hline \multicolumn{5}{|l|}{ Memory } \\
\hline \multicolumn{5}{|l|}{ Short term memory } \\
\hline Digit span forward & 5 & & 3.75 & \\
\hline \multicolumn{5}{|l|}{ Anterograde long term memory } \\
\hline Prose memory & 12.3 & $/ 16$ & 4.75 & \\
\hline Paired-associate word & 2 & $/ 22.5$ & 6.5 & Impaired \\
\hline Rey-Osterrieth complex figure (recall) & 4 & 136 & 9.47 & Impaired \\
\hline \multicolumn{5}{|l|}{ Semantic memory } \\
\hline Picture to picture matching task & 23 & 130 & 25 & Impaired \\
\hline Word to word matching task & 14 & 130 & 24 & Impaired \\
\hline Celebrities identification task & 0 & $/ 60$ & & Impaired \\
\hline Vocabulary task & 1 & $/ 10$ & & Impaired \\
\hline Retrograde memory test (verbal section) & 0 & 144 & & Impaired \\
\hline \multicolumn{5}{|l|}{ Language } \\
\hline Picture naming task & 58 & $/ 80$ & 61 & Impaired \\
\hline \multicolumn{5}{|l|}{ Achener Aphasia Test (AAT) } \\
\hline Token test & 10 & $/ 0$ & 7 & Impaired \\
\hline Repetition & 142 & $/ 150$ & 142 & \\
\hline Written language & 88 & 190 & 81 & \\
\hline Naming & 97 & $/ 120$ & 104 & Impaired \\
\hline Comprehension & 102 & $/ 120$ & 108 & Impaired \\
\hline \multicolumn{5}{|l|}{ Praxis } \\
\hline De Renzi test (right) & 72 & 172 & 53 & \\
\hline De Renzi test (left) & 70 & 172 & 53 & \\
\hline \multicolumn{5}{|l|}{ Visual attention } \\
\hline Bell's test & 34 & $/ 35$ & 30 & \\
\hline Digit cancellation task & 47 & $/ 60$ & 31 & \\
\hline \multicolumn{5}{|l|}{ Visuospatial functions } \\
\hline Clock Drawing Test (CDT) & 5 & 15 & 3 & \\
\hline Copy of geometrical figures & 13 & $/ 14$ & 8 & \\
\hline Rey-Osterrieth complex figure (copy) & 35 & 136 & 28.88 & \\
\hline
\end{tabular}

Impaired $=$ score $<5$ th percentile.

before cognitive and psychotic symptoms. The neurological examination was unremarkable, apart from mild hypomimia. No signs of motor neuron disease were observed. Cognitive screening was normal $(\mathrm{MMSE}=29 / 30 ; \mathrm{CDT}=5 / 5)$. Behavioral examination was mildly pathological (NPI $=19 / 144)$, the GDS was negative for depression (2/30), and functional autonomy was still preserved $(\mathrm{ADL}=6 / 6$; IADL $=5 / 5)$. The neuropsychological examination disclosed severe deficits in all semantic tasks, involving word-, object-, and face-processing. The verbal matching task was more impaired than its visual counterpart (Table 1). There were also severe deficits in the vocabulary task, a mild pre-frontal dysexecutive syndrome, and a slight loss of insight $(C I R=3 / 8)$. Moreover, mild social inappropriateness and verbal disinhibition emerged at the clinical interview. Anterograde amnesia was revealed by the visual delayed recall and verbal learning tasks. Retrograde amnesia emerged on recalling medical history and autobiographical information, and was 


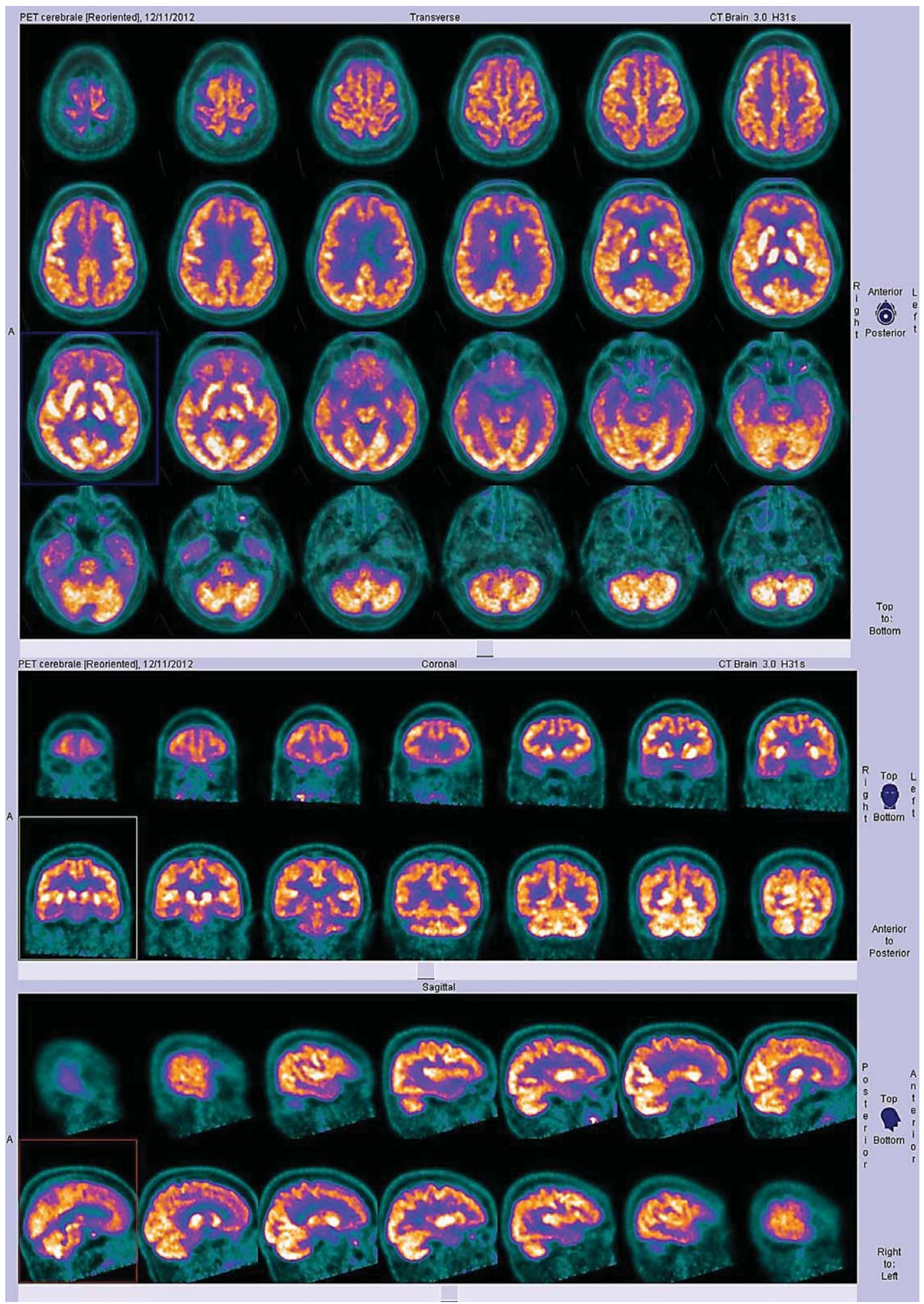

Fig. 1. FDG-PET scan demonstrating diffuse cortical hypometabolism, more pronounced on bilateral basal frontal and temporal polar cortex. 
confirmed by a retrograde memory test. Short-term memory was preserved. Speech was fluent, with rare pass-partout words and perseverations, and there were no signs of dysartria. Repetition was preserved, while significant deficit were found in naming tasks (Table 1). There were some difficulties in comprehension tasks (AAT), more pronounced for single words (48/60) than for sentences (54/60). There was no dyslexia and dysgraphia (AAT), no impairment in visual attention and visuospatial functions, and no limb and limbkinetic apraxia. There was evidence of both temporal and contextual disorientation. From the instrumental examinations, different findings emerged. EEG showed a minimal hyperventilation-induced slowing across the fronto-temporal regions, with a left-sided predominance. The brain MRI scan showed diffuse cortical and subcortical atrophy, particularly affecting the left hemisphere, and mild subcortical vascular damage. The FDG-PET scan demonstrated diffuse cortical hypometabolism, with a more marked involvement of the basofrontal and temporopolar cortex bilaterally (Fig. 1). With regard to biomarkers, CSF $\mathrm{A} \beta$, tau, and p-tau were not altered $(1242 \mathrm{pg} / \mathrm{ml}, 375 \mathrm{pg} / \mathrm{ml}$, and $31 \mathrm{pg} / \mathrm{ml}$, respectively) and nor were plasma progranulin levels $(215 \mathrm{ng} / \mathrm{ml})$. On genetic testing the patient was found to be a carrier of the C9ORF72 hexanucleotide repeat expansion. Based on the genetic, instrumental, clinical, and neuropsychological data, a tentative diagnosis of SD was therefore made, according to current criteria [25-27]. At a follow-up visit, one year later, the patient's relatives reported further worsening of both apathy and cognitive impairment. The neurological examination was unchanged. While the CDT was still normal (5/5), the MMSE had dropped to 22 , the NPI score was a little higher (25/144), and there was a decrease in functional autonomy $(\mathrm{ADL}=5 / 6$; $\mathrm{IADL}=0 / 5$ ).

\section{DISCUSSION}

In this report, we describe a patient with the repeat expansion in the C9ORF72 gene, presenting with a clinical phenotype with prominent behavioral changes and semantic deficits. The core clinical feature was a profound semantic dysfunction, with loss of word meaning, impaired face and object recognition, and better comprehension for sentences than for single words. The bilateral basofrontal and temporopolar cortex hypometabolism found on brain imaging is compatible with an intermediate stage of SD [26]. Moreover, the asymmetric pattern of atro- phy, with left sided predominance, well matches the more severe impairment of the verbal than visual semantics. Interestingly, the patient reported early hyposmia, in accordance with previous data showing a severe impairment in olfactory identification in SD patients, despite normal perceptual discrimination [28]. Moreover, the loss of olfactory as well as of visual knowledge has been supposed to contribute to the dietary changes observed in such patients [28]. Another patient with the C9ORF72 mutation and a SD phenotype has been reported to be apparently unable to recognize foods by taste [14]. Although semantic dysfunction was predominant, behavioral changes, other cognitive deficits, and mild psychotic symptoms were found to be associated with semantic disorders in this case. Indeed, behavioral changes, like the ones displayed by our patient, have been described in SD [26] even if compulsive gambling and signs of social disinhibition are not typical SD features. Anterograde dysmnesia with temporal disorientation and delusions appear to be less compatible with SD, but memory impairment [7-9, 14] and psychotic symptoms [3, 4, $11,13,14]$ have often been reported in C9ORF72 mutation carriers. Actually, considering the imaging pattern and the heterogeneity of the clinical features, an alternative diagnosis of bvFTD with temporal involvement and associated semantic deficits cannot be excluded.

In conclusion, we described a patient with the repeat expansion in the C9ORF72 gene presenting with behavioral changes and semantic deficits, thus supporting the heterogeneity of the clinical presentation of the C9ORF72 mutation. However, the method used allowed us to visualize 30 repetitions. Therefore, we cannot rule out a correlation between the length of the expansion and the clinical phenotype, age at onset, and course of the disease. In this regard, additional genetic, epigenetic, or environmental factors could contribute to determining the age at onset as well as the heterogeneity of symptoms, although no definite conclusions on this issue have been reached yet.

\section{DISCLOSURE STATEMENT}

Authors' disclosures available online (http://www.jalz.com/disclosures/view.php?id=2078).

\section{REFERENCES}

[1] DeJesus-Hernandez M, Mackenzie IR, Boeve BF, Boxer AL, Baker M, Rutherford NJ, Nicholson AM, Finch NA, Flynn H, Adamson J, Kouri N, Wojtas A, Sengdy P, Hsiung GY, Karydas A, Seeley WW, Josephs KA, Coppola G, Geschwind 
DH, Wszolek ZK, Feldman H, Knopman DS, Petersen RC, Miller BL, Dickson DW, Boylan KB, Graff-Radford NR, Rademakers R (2011) Expanded GGGGCC hexanucleotide repeat in noncoding region of C9ORF72 causes chromosome 9p-linked FTD and ALS. Neuron 72, 245-256.

[2] Renton AE, Majounie E, Waite A, Simón-Sánchez J, Rollinson S, Gibbs JR, Schymick JC, Laaksovirta H, van Swieten JC, Myllykangas L, Kalimo H, Paetau A, Abramzon Y, Remes AM, Kaganovich A, Scholz SW, Duckworth J, Ding J, Harmer DW, Hernandez DG, Johnson JO, Mok K, Ryten M, Trabzuni D, Guerreiro RJ, Orrell RW, Neal J, Murray A, Pearson J, Jansen IE, Sondervan D, Seelaar H, Blake D, Young K, Halliwell N, Callister JB, Toulson G, Richardson A, Gerhard A, Snowden J, Mann D, Neary D, Nalls MA, Peuralinna T, Jansson L, Isoviita VM, Kaivorinne AL, Hölttä-Vuori M, Ikonen E, Sulkava R, Benatar M, Wuu J, Chiò A, Restagno G, Borghero G, Sabatelli M, Consortium ITALSGEN, Heckerman D, Rogaeva E, Zinman L, Rothstein JD, Sendtner M, Drepper C, Eichler EE, Alkan C, Abdullaev Z, Pack SD, Dutra A, Pak E, Hardy J, Singleton A, Williams NM, Heutink P, Pickering-Brown S, Morris HR, Tienari PJ, Traynor BJ (2011) A hexanucleotide repeat expansion in C9ORF72 is the cause of chromosome 9p21-linked ALS-FTD. Neuron 72, 257268.

[3] Dobson-Stone C, Hallupp M, Bartley L, Shepherd CE, Halliday GM, Schofield PR, Hodges JR, Kwok JB (2012) C9ORF72 repeat expansion in clinical and neuropathologic frontotemporal dementia cohorts. Neurology 79, 9951001.

[4] Snowden JS, Rollinson S, Thompson JC, Harris JM, Stopford CL, Richardson AM, Jones M, Gerhard A, Davidson YS, Robinson A, Gibbons L, Hu Q, DuPlessis D, Neary D, Mann DM, Pickering-Brown SM (2012) Distinct clinical and pathological characteristics of frontotemporal dementia associated with C9ORF72 mutations. Brain 135, 693-708.

[5] Hsiung GY, DeJesus-Hernandez M, Feldman HH, Sengdy P, Bouchard-Kerr P, Dwosh E, Butler R, Leung B, Fok A, Rutherford NJ, Baker M, Rademakers R, Mackenzie IR (2012) Clinical and pathological features of familial frontotemporal dementia caused by C9ORF72 mutation on chromosome 9p. Brain 135(Pt 3), 709-722.

[6] Simón-Sánchez J, Dopper EG, Cohn-Hokke PE, Hukema RK, Nicolaou N, Seelaar H, de Graaf JR, de Koning I, van Schoor NM, Deeg DJ, Smits M, Raaphorst J, van den Berg LH, Schelhaas HJ, De Die-Smulders CE, Majoor-Krakauer D, Rozemuller AJ, Willemsen R, Pijnenburg YA, Heutink P, van Swieten JC (2012) The clinical and pathological phenotype of C9ORF72 hexanucleotide repeat expansions. Brain 135, 723-735.

[7] Mahoney CJ, Beck J, Rohrer JD, Lashley T, Mok K, Shakespeare T, Yeatman T, Warrington EK, Schott JM, Fox NC, Rossor MN, Hardy J, Collinge J, Revesz T, Mead S, Warren JD (2012) Frontotemporal dementia with the C9ORF72 hexanucleotide repeat expansion: Clinical, neuroanatomical and neuropathological features. Brain 135, 736-750.

[8] Boeve BF, Boylan KB, Graff-Radford NR, DejesusHernandez M, Knopman DS, Pedraza O, Vemuri P, Jones D, Lowe V, Murray ME, Dickson DW, Josephs KA, Rush BK, Machulda MM, Fields JA, Ferman TJ, Baker M, Rutherford NJ, Adamson J, Wszolek ZK, Adeli A, Savica R, Boot B, Kuntz KM, Gavrilova R, Reeves A, Whitwell J, Kantarci K, Jack CR Jr, Parisi JE, Lucas JA, Petersen RC, Rademakers $R$ (2012) Characterization of frontotemporal dementia and/or amyotrophic lateral sclerosis associated with the GGGGCC repeat expansion in C9ORF72. Brain 135, 765-783.
[9] Galimberti D, Fenoglio C, Serpente M, Villa C, Bonsi R, Arighi A, Fumagalli GC, Del Bo R, Bruni AC, Anfossi M, Clodomiro A, Cupidi C, Nacmias B, Sorbi S, Piaceri I, Bagnoli S, Bessi V, Marcone A, Cerami C, Cappa SF, Filippi M, Agosta F, Magnani G, Comi G, Franceschi M, Rainero I, Giordana MT, Rubino E, Ferrero P, Rogaeva E, Xi Z, Confaloni A, Piscopo P, Bruno G, Talarico G, Cagnin A, Clerici F, Dell'Osso B, Comi GP, Altamura AC, Mariani C, Scarpini E (2013) Autosomal dominant frontotemporal lobar de generation due to the C9ORF72 hexanucleotide repeat expansion: Late-onset psychotic clinical presentation. Biol Psychiatry 74, 384-391.

[10] Irwin, DJ, McMillan CT, Brettschneider J, Libon DJ, Powers J, Rascovsky K, Toledo JB, Boller A, Bekisz J, Chandrasekaran K, McCarty Wood E, Shaw LM, Woo JH, Cook PA, Wolk DA, Arnold SE, Van Deerlin VM, McCluskey LF, Elman L, Lee VM-Y, Trojanowski JQ, Grossman M (2013) Cognitive decline and reduced serviva in C9ORF72 expansion frontotemporale de generation and amyotrophic lateral sclerosis. J Neurol Neurosurg Psychiatry 84, 163-169.

[11] Arighi A, Fumagalli GG, Jacini F, Fenoglio C, Ghezzi L, Pietroboni AM, De Riz M, Serpente M, Ridolfi E, Bonsi R, Bresolin N, Scarpini E, Galimberti D (2012) Early onset behavioral variant frontotemporal dementia due to the C9ORF72 hexanucleotide repeat expansion: Psychiatric clinical presentations. J Alzheimers Dis 31, 447-452.

[12] Calvo A, Moglia C, Canosa A, Cistaro A, Valentini C, Carrara G, Soldano E, Ilardi A, Bersano E, Bertuzzo D, Brunetti M, Ossola I, Restagno G, Chiò A (2012) Amyotrophic lateral sclerosis/frontotemporal dementia with predominant manifestations of obsessive-compulsive disorder associated to GGGGCCexpansion of the c9orf72 gene. J Neurol 259, 27232725.

[13] Floris G, Borghero G, Cannas A, Di Stefano F, Costantino E, Murru MR, Brunetti M, Restagno G, Traynor BJ, Marrosu MG, Chiò A, Marrosu F (2012) Frontotemporal dementia with psychosis, parkinsonism, visuo-spatial dysfunction, upper motor neuron involvement associated to expansion of C9ORF72: A peculiar phenotype? J Neurol 259, 1749-1751.

[14] Cerami C, Marcone A, Galimberti D, Zamboni M, Fenoglio C, Serpente M, Scarpini E, Cappa SF (2013) Novel evidence of phenotypical variability in the exanucleotide repeat expansion in chromosome 9. J Alzheimers Dis 35, 455-462.

[15] Gómez-Tortosa E, Gallego J, Guerrero-López R, a MARCOS, Gil-Neciga E, Sainz MJ, Díaz A, Franco-Macías E, Trujillo-Tiebas MJ, Ayuso C, Pérez-Pèrez J (2013) C9ORF72 hexanucleotide expansions of 20-22 repeats are associated with frontotemporal deterioration. Neurology 80, 366-370.

[16] Hodges JR, Mitchell J, Dawson K, Spillantini MG, Xuereb JH, McMonagle P, Nestor PJ, Patterson K (2010) Semantic dementia: Demography, familial factors and survival in a consecutive series of 100 cases. Brain 133, 300-306.

[17] Spinnler H, Tognoni G (1987) Standardizzazione e taratura italiana di test neuropsicologici. Ital J Neurol Sci 8(Suppl 8), 1-120.

[18] Gauthier L, Dehaut F, Joanette Y (1989) The bells test: A quantitative and qualitative test for visual neglect. Int J Clin Neuropsychol 11, 49-54.

[19] Visch-Brink E, Denes G (1993) A European base-line test for word-picture processing. In Developments in the Assessment $\&$ Rehabilitation of Brain-Damaged Patients. Perspectives from an European Concerted Action, Stachoviack FJ, ed. Gunter Narr Verlag, Tubingen, pp. 211-219.

[20] Manera M, Zonca G, Pistarini C, La Manna A, Luzzatti C (2006) Batteria per la diagnosi dei disturbi prosopagnosici 
e descrizione di due casi clinici. Proceedings of the Annual Meeting of the Società Italiana di Riabilitazione Neurologica, Venezia Lido, April 6-8, p. 106.

[21] Dalla Barba G (1993) Confabulation, knowledge and recollective experience. Cogn Neuropsychol 10, 1-20.

[22] Andreani O, Amoretti G, Baldi P (1990) MLT' 88: Test di memoria di eventi storici, Organizzazioni Speciali, Firenze.

[23] Laiacona M, Barbarotto R, Trivelli C, Capitani E (1993) Dissociazioni semantiche intercategoriali: Descrizione di una batteria standardizzata e dati normativi. Arch Psicol Neurol Psichiatr 54, 209-248.

[24] Miller SA, Dykes DD, Polesky HF (1988) A simple salting out procedure for extracting DNA from human nucleated cells. Nucleic Acids Res 16, 1215.

[25] Neary D, Snowden JS, Gustafson L, Passant U, Stuss D, Black S, Freedman M, Kertesz A, Robert PH, Albert M, Boone K, Miller BL, Cummings J, Benson DF (1998) Frontotemporal lobar degeneration. A consensus on clinical diagnostic criteria. Neurology 51, 1546-1554.

[26] Hodges JR, Patterson K (2007) Semantic dementia: A unique clinicopathological syndrome. Lancet Neurol 6, 1004-1014.

[27] Gorno-Tempini ML, Hillis AE, Weintraub S, Kertesz A, Mendez M, Cappa SF, Ogar JM, Rohrer JD, Black S, Boeve BF, Manes F, Dronkers NF, Vandenberghe R, Rascovsky K, Patterson K, Miller BL, Knopman DS, Hodges JR, Mesulam MM, Grossman M (2011) Classification of primary progressive aphasia and its variants. Neurology 76, 1006-1014.

[28] Luzzi S, Snowden JS, Neary D, Coccia M, Provinciali L, Lambon Ralph MA (2007) Distinct patterns of olfactory impairment in Alzheimer's disease, semantic dementia, frontotemporal dementia, and corticobasal degeneration. Neuropsychologia 45, 1823-1831. 